\title{
ANALISIS SISTEM INFORMASI AKUNTANSI PENGGAJIAN DALAM RANGKA EFEKTIVITAS PENGENDALIAN INTERNAL PERUSAHAAN (Studi Kasus pada PT. Populer Sarana Medika, Surabaya)
}

\author{
Yenni Vera Fibriyanti \\ Universitas Wijaya Kusuma Surabaya
}

\begin{abstract}
ABSTRAK
Penelitian ini bertujuan untuk menganalisa sistem informasi akuntansi penggajian yang telah diterapkan PT. Populer Sarana Medika dan juga untuk menganalisa sistem informasi akuntansi penggajian pada efektivitas pengendalian internal. Jenis penelitian yang dilakukan adalah penelitian deskriptif, yang berfokus pada sistem informasi akuntansi penggajian pada PT. Populer Sarana Medika dan sistem pengendalian intern pada PT. Populer Sarana Medika. Analisis data dalam penelitian ini dimulai dengan menganalisa fungsi - fungsi yang terkait, dokumen pendukung, catatan akuntansi yang digunakan, jaringan prosedur dan menilai efektifitas pengendalian internal. Hasil penelitian menemukan bukti bahwa Bagian Akuntansi masih bertanggungjawab dalam pembayaran gaji dan upah karyawan serta masih bertanggungjawab melakukan pengawasan terhadap pengisian daftar hadir karyawan dan membuat rekap daftar hadir karyawan sehingga memungkinkan adanya penyelewengan. Praktek yang sehat yang diterapkan untuk mendukung efektifitas pengendalian intern adalah gaji pokok karyawan dibayarkan dengan mentransfer gaji pokok ke rekening masing - masing karyawan oleh direktur dan slip gaji dibuat rangkap dua.
\end{abstract}

Kata kunci : Sistem Informasi Akuntansi Penggajian, Efektivitas Pengendalian Intern

\section{PENDAHULUAN}

Pada era globalisasi sekarang ini perusahaan dituntut untuk lebih efisien, efektif, dan ekonomis dalam menentukan besarnya biaya operasional perusahaan, karena faktor ini adalah salah satu yang terpenting untuk menghadapi persaingan yang semakin ketat dengan perusahaan lain. Dalam melaksanakan kegiatan operasi perusahaan diperlukan adanya manajemen perusahaan yang baik dengan ditunjang oleh personil yang berkualitas agar dapat berkarya secara efisien.

$$
\text { Perkembangan teknologi yang }
$$
semakin meningkat juga mempengaruhi perkembangan kinerja dalam mencapai tujuan perusahaan. Semakin meningkatnya teknologi dalam menjalankan kegiatan operasional tentunya juga harus didukung dengan adanya sumber daya manusia atau karyawan yang berkualitas untuk mendukung tercapainya tujuan utama 
perusahaan. Kinerja sumber daya jumlahnya cukup besar dapat manusia atau karyawan juga akan meningkatkan risiko pengunaan gaji dan didukung dengan diterapkannya sistem informasi akuntansi pada perusahaan. upah yang tidak semestinya.

Sistem pengendalian intern "Sistem informasi akuntansi (SIA) adalah kumpulan sumber daya, seperti manusia dan peralatan yang diatur untuk mengubah data keuangan dan data lainnya menjadi informasi" (Bodnar dan Hopwood, 2003: 1).

Untuk menjalankan kegiatannya dengan efektif dan efisien, sebuah perusahaan memerlukan suatu sistem pengolahan data informasi yang mendukungnya. Kebutuhan ini akan terpenuhi dengan adanya sistem informasi akuntansi. Sistem informasi akuntansi harus dirancang dan digunakan secara efektif, karena informasi akuntansi merupakan bagian yang paling penting dari seluruh informasi yang diperlukan oleh manajemen.

Sistem informas akuntansi dalam perusahaan dapat membantu pihak pihak manajemen memperoleh informasi yang tepat dalam pengambilan keputusan untuk mencapai tujuan utama perusahaan termasuk dalam hal pemberian atau pembayaran kompensasi kepada karyawan yang berupa gaji dan upah. Biaya gaji dan upah yang merupakan proses pemantauan yang memungkinkan manajemen mengetahui apakah tindakan yang dilakukan dan bagaimanakah tindakan koreksinya jika pelaksanaan tidak sesuai dengan yang telah ditetapkan semula. Suatu sistem pengendalian intern dikatakan memadai jika dengan diterapkannya sistem tersebut semua tujuan perusahaan dapat tercapai. Tujuan tersebut adalah pengamanan atau menjaga aktiva yang dimiliki, memeriksa ketelitian dan kebenaran data akuntansi, menjamin adanya efisiensi dalam operasional serta menjaga agar tidak terjadi penyimpangan dari kebijakan yang telah ditetapkan, dengan demikian dapat dilihat bahwa sistem pengendalian intern mempunyai peranan yang penting sekali bagi perusahaan.

PT. Populer Sarana Medika adalah sebuah perusahaan yang bergerak dalam bidang jasa pelayanan pemeriksaan laboratorium klinik yang tentunya mempunyai Sumber Daya Manusia (SDM) cukup banyak dengan tingkat keahlian dan pendidikan yang tinggi. Dari berbagai transaksi pada perusahaan, 
kegiatan penggajian dan pengupahan mewakili transaksi yang penting dalam rangka pengendalian intern. Pengendalian atas gaji dan upah harus dilakukan dengan penuh ketelitian dan kecermatan agar transaksi tersebut tidak mengakibatkan kerugian yang harus diderita oleh perusahaan.

Berdasarkan latar belakang tersebut, tujuan yang ingin dicapai dalam penelitian ini adalah sebagai berikut:

1. Untuk menganalisa sistem informasi akuntansi penggajian yang telah diterapkan PT. Populer Sarana Medika.

2. Untuk menganalisa sistem informasi akuntansi penggajian pada efektivitas pengendalian internal PT. Populer Sarana Medika.

\section{TINJAUAN PUSTAKA}

\subsection{Pengertian Sistem Informasi} Akuntansi

Menurut Bodnar dan Hopwood (2003: 1) : "Sistem informasi akuntansi (SIA) adalah kumpulan sumber daya, seperti manusia dan peralatan yang diatur untuk mengubah data keuangan dan data lainnya menjadi informasi”. Informasi ini kemudian dikomunikasikan kepada berbagai pihak pengambil keputusan.
Mulyadi (2001: 3) menyatakan bahwa "sistem informasi akuntansi adalah organisasi formulir, catatan, dan pelaporan yang dikoordinasikan sedemikian rupa untuk menyediakan informasi keuangan yang dibutuhkan oleh manajemen guna memudahkan pengelolaan data perusahaan".

Sistem informasi akuntansi merupakan suatu prosedur yang digunakan dalam menyampaikan data kegiatan terutama yang berhubungan dengan informasi keuangan kepada pihak yang berkepentingan. Adapun unsur dari sistem akuntansi adalah formulir, catatan, peralatan yang digunakan untuk mengolah data dalam menghasilkan informasi keuangan yang diperlukan oleh manajemen. (Hidayat, dkk, 2013)

\subsection{Sistem Informasi Akuntansi Penggajian}

Menurut Mulyadi (2001: 12) "sistem akuntansi penggajian dirancang untuk menangani transaksi perhitungan gaji karyawan dan pembayarannya". Mulyadi (2001: 285) "sistem informasi akuntansi penggajian digunakan untuk melaksanakan perhitungan, pembayaran, dan pencatatan gaji bagi karyawan yang dibayar tetap bulanan". 
Mulyadi (2001: 373) memberikan definisi gaji adalah sebagai berikut: gaji merupakan pembayaran atas penyerahan jasa yang dilakukan oleh karyawan yang mempunyai jenjang jabatan manajer, umumnya gaji diberikan secara tetap perbulan.

Sedangkan menurut Manullang (2001: 57) gaji adalah pemberian kepada pegawai dengan pembayaran berupa uang sebagai balas jasa suatu pekerjaan yang telah dilaksanakan sebagai pemberian kegairahan untuk pelaksanaan dan kegiatan diwaktu yang akan datang.

Berdasarkan beberapa pendapat tersebut, pada dasarnya sistem informasi akuntansi penggajian adalah sistem informasi akuntansi yang digunakan untuk menangani atau melaporkan transaksi - transaksi dan memberikan informasi terkait dengan penggajian karyawan.

\subsection{Efektifitas}

Efektivitas kadang dijadikan sebagai tolak ukur atas suatu keberhasilan perusahaan. Apabila kegiatan berjalan dengan efektif maka suatu perusahaan dapat dikatakan sudah berhasil. Efektivitas perusahaan adalah kemampuan suatu perusahaan untuk mencapai tujuan yang diinginkan dengan memanfaatkan sumber daya yang dimilikinya (Danke, 2012). Semakin sedikit sumber daya yang dipakai untuk menghasilkan sesuatu yang lebih banyak dapat dikatakan perusahaan sudah mencapai efektivitasnya.

\subsection{Pengendalian Internal dalam sistem informasi akuntansi penggajian}

Pengendalian internal adalah suatu aktivitas berupa prosedur-prosedur yang harus dilakukan untuk memberi keyakinan yang layak bahwa suatu kegiatan yang dilakukan tidak menyimpang dari yang seharusnya. Pengendalian internal saat ini makin dibutuhkan oleh perusahaan yang ingin menjalankan kegiatannya secara efektif dan efisien (Danke, 2012).

Menurut (Saraswati, 2014), pada dasarnya sistem pengendalian intern adalah kesatuan dari struktur organisasi serta alat - alat yang mendukung untuk melakukan pengawasan terhadap kegiatan - kegiatan yang berhubungan dengan penggunaan harta milik perusahaan serta untuk meminimalkan terjadinya kesalahan, kecurangan dan penyelewengan yang terjadi pada perusahaan agar kegiatan operasional perusahaan dapat berjalan dengan lancar 
untuk mendukung tercapainya tujuan utama perusahaan.

Tujuan pengendalian internal seperti yang dikemukan oleh Elder, Beasley, dan Arens (2009:242) yang diterjemahkan oleh Amir Abadi Yusuf adalah:

1. Efektivitas dan efisiensi operasi.

Pengendalian internal bertujuaan untuk mencapai efektivitas dan efisiensi dalam kegiatan operasi perusahaan, hal ini termasuk pelaksanaan kegiatan, pencapaian hasil, dan usaha perlindungan terhadap kerugian. Pengendalian internal dibutuhkan atas sumber daya yang dimiliki perusahaan, agar sumber daya ini tidak disalahgunakan oleh orang-orang atau pihak yang tidak berkepentingan dan tidak berwenang. Manajemen harus memiliki data dan informasi yang akurat agar pengambilan keputusan dapat dilakukan secara cepat dan tepat.

2. Realibilitas atas Pelaporan Keuangan

Manajemen bertanggung jawab atas pelaporan keuangan yang diterbitkan oleh perusahaan. Pengendalian internal bertujuan agar pelaporan keuangan yang diterbitkan dapat dipercaya, hal ini termasuk pencegahan atas kecurangan pada pelaporan keuangan. Kecurangan atas pelaporan keuangan biasanya disebabkan karena permintaan dari pihak eksternal. Pengendalian internal bertujuan agar pelaporan keuangan yang ada dapat sesuai dengan prinsip akuntansi yang berlaku umum.

3. Kepatuhan terhadap Hukum dan Peraturan

Pengendalian internal bertujuan untuk memastikan bahwa segala peraturan dan ketetapan yang sudah dibuat oleh perusahaan sudah dipatuhi dengan baik dan benar oleh para karyawannya. Pengendalian internal dapat mengendalikan kegiatan perusahaan agar dapat sesuai dengan peraturan dan hukum yang berlaku.

\section{METODOLOGI PENELITIAN}

Jenis penelitian yang digunakan dalam penelitian ini adalah penelitian deskriptif dengan metode analisis data yaitu analisis data kualitatif. Menurut Mardalis (2010:26) penelitian deskriptif, bertujuan untuk mendeskripkan apa apa yang saat ini berlaku. Di dalamnya 
terdapat upaya mendeskripsikan, mencatat, analisis dan mengintreprestasikan kondisi - kondisi yang sekarang ini terjadi atau ada. Dengan kata lain penelitian deskriptif bertujuan untuk memperoleh informasi informasi mengenai keadaan saat ini, dan melihat kaitan antara variabel variabel yang ada. Penelitian ini tidak menguji hipotesa atau tidak menggunakan hipotesa, melainkan hanya mendeskripsikan informasi apa adanya sesuai dengan variabel - variabel yang diteliti

Berdasarkan pendapat tersebut, pada dasarnya penelitian deskriptif dilakukan untuk mengamati dan mengetahui suatu objek penelitian dengan lebih jelas dengan tujuan agar dapat mendeskripkan objek penelitian sesuai dengan fakta yang ada dan dapat membandingkan antara teori dan praktik yang terjadi di lapangan, sehingga dapat ditemukan solusi untuk permasalahan yang timbul pada objek penelitian. Penelitian ini berfokus pada sistem informasi akuntansi penggajian dan sistem pengendalian intern pada PT. Populer Sarana Medika.

Metode pengumpulan data yang digunakan adalah wawancara, dokumentasi dan observasi. Dalam metode ini dilakukan dengan cara tanya jawab secara langsung mengenai sistem informas akuntansi penggajian karyawan kepada bagian keuangan, bagian penggajian dan bagian administrasi. Penulis juga melakukan pengamatan secara langsung terhadap sistem pengendalian intern penggajian karyawan pada perusahaan. Data yang diperoleh misalnya dokumen pernyataan gaji, kartu absensi, formulir-formulir dalam prosedur penggajiannya, daftar gaji dan rekap daftar gaji. Dalam metode ini penulis membuat catatan kecil, membaca laporan akhir tahun sebelumnya yang ada pada perusahaan yang berguna untuk menyusun gambaran umum perusahaan. Penerapan sistem informasi akuntansi penggajian yang belum efektif akan diberikan alternatif pemecahan masalah untuk membantu perusahaan menerapkan sistem akuntansi penggajian dan pengupahan yang efektif.

Analisis data dalam penelitian ini dimulai dengan menganalisa sistem informasi akuntansi penggajian yang telah diterapkan perusahaan dengan cara melakukan analisis terhadap fungsi fungsi yang terkait, analisis terhadap dokumen yang digunakan, analisis terhadap catatan akuntansi yang digunakan dan analisis terhadap jaringan 
prosedur yang membentuk sistem informasi akuntansi penggajian pada perusahaan. Menganalisis dan menilai efektifitas pengendalian internal yang dimiliki oleh perusahaan yang berkaitan dengan sistem akuntansi penggajian yang terdiri dari analisis struktur organisasi, analisis sistem otorisasi dan prosedur pencatatan, analisis praktik yang sehat dan karyawan yang sesuai dengan mutunya.

\section{PEMBAHASAN}

\subsection{Analisis Sistem Informasi Akuntansi Penggajian pada PT. Populer Sarana Medika}

Penggajian bagi para karyawan di PT. Populer Sarana Medika didasarkan pada kemampuan suatu lembaga sebagai standar gaji pokoknya, kemudian ditambah tunjangan jabatan, tunjangan transport, uang makan, dan premi hadir, selanjutnya dikurangi dengan potongan gaji seperti utang gaji karyawan. Ketentuan besarnya tunjangan yang diberikan kepada karyawan ini diperhitungkan berdasarkan jabatan dan masa kerja karyawan yang bersangkutan. PT. Populer Sarana Medika memberikan tunjangan atau jaminan sosial kepada karyawannya dalam rangka usaha pemeliharaan tenaga kerja.
Penerapan atau pelaksanaan penggajian karyawan pada PT. Populer Sarana Medika sudah cukup baik dan sudah sesuai dengan teori yang ada. Besar gaji pokok yang diterima masing masing karyawan ditentukan oleh pihak manajemen sesuai jabatan masing masing karyawan. Namun penerapan atau pelaksanaan penggajian di PT. Populer Sarana Medika masih terdapat kelemahan diantaranya tidak ada uang transport bagi karyawan yang tinggal di mess. Pihak manajemen mengasumsikan bahwa karyawan yang tinggal di mess tidak membutuhkan uang transport karena lokasi mess berada satu tempat dengan perusahaan.

\subsection{Analisis Fungsi - Fungsi yang} Terkait dalam Sistem Informasi Akuntansi Penggajian pada PT. Populer Sarana Medika

Fungsi - fungsi yang terkait dalam sistem informasi akuntansi penggajian pada PT. Populer Sarana Medika adalah

a. Bagian Akuntansi

Bagian akuntansi bertugas untuk membuat rekap daftar hadir karyawan, daftar gaji karyawan, slip gaji, lembar penerimaan gaji, bukti kas keluar, dan 
bertanggung jawab mencatat transaksi - transaksi penggajian pada jurnal umum dan buku besar.

b. Direktur

Direktur berwenang dalam proses pembayaran gaji pokok karyawan. Melakukan transfer gaji pokok, tunjangan jabatan, tunjangan transport, uang makan, dan premi hadir ke rekening masing - masing karyawan dan mentransfer biaya pembayaran pendapatan per bulan ke rekening Bagian Akuntansi melalui E-bankin ( Electronic Banking ).

Fungsi-fungsi yang terkait dengan sistem informasi akuntansi penggajian pada PT. Populer Sarana Medika kurang baik dan belum sesuai dengan teori yang ada. Alternatif - alternatif untuk mengurangi kelemahan pada fungsi fungsi yang terkait dalam sistem informasi akuntansi penggajian antara lain : Terdapat bagian khusus seperti fungsi pembuat daftar gaji (bagian akuntansi) yang bertanggung jawab untuk membuat daftar gaji yang berisi gaji pokok serta tunjangan-tunjangan yang diberikan kepada karyawan dan potongan-potongan yang menjadi beban karyawan setiap bulannya. Daftar gaji tersebut dikelola oleh fungsi pembuat daftar gaji guna pembuatan daftar gaji yang akan diajukan ke kasir, untuk pembayaran gaji pegawai. Selain itu, harus ada fungsi pencatat waktu (bagian personalia) yang bertanggungjawab untuk membuat rekap daftar hadir karyawan dan menyelenggarakan waktu hadir bagi semua karyawan PT. Populer Sarana Medika. Sistem pengendalian intern yang baik mensyaratkan fungsi pencatatan waktu hadir karyawan tidak boleh dilaksanakan oleh fungsi operasi atau oleh fungsi pembuat daftar gaji dan upah.

\subsection{Analisis Dokumen - Dokumen} yang Digunakan dalam Sistem Informasi Akuntansi Penggajian pada PT. Populer Sarana Medika

Dokumen - Dokumen yang digunakan dalam sistem informasi akuntansi penggajian pada PT. Populer Sarana Medika meliputi :

a. Daftar Hadir Karyawan

Daftar hadir karyawan digunakan untuk mencatat kehadiran karyawan setiap hari pada saat datang sebelum memulai kerja dan pulang kerja 
dengan melakukan finger print (check clock).

b. Rekap Daftar Hadir Karyawan Rekap daftar hadir digunakan untuk mencatat rekap jam hadir karyawan tetap yang dihitung selama satu bulan.

c. Daftar Gaji Karyawan

Daftar gaji karyawan digunakan untuk mencatat jumlah gaji pokok dari masing - masing karyawan, ditambah tunjangantunjangan dan dikurangi potongan-potongan.

d. Slip Gaji

Slip gaji dibuat oleh Bagian Akuntansi yang berisi rincian gaji yang diterima oleh karyawan.

e. Bukti Transfer

Bukti transfer digunakan sebagai bukti bahwa gaji pokok telah ditransfer ke rekening masing masing karyawan sesuai besar gaji pokok yang ditetapkan oleh pihak manajemen.

Dokumen - dokumen untuk penggajian pada PT. Populer Sarana Medika sudah cukup baik dan sudah sesuai dengan teori yang ada. Dokumen yang digunakan sudah cukup memadai dalam mendukung pengendalian intern gaji yang baik. Karena perusahaan memanfaatkan teknologi informasi, maka pemrosesan penggajian dibuat lebih efisien. Hal ini memberikan penghematan biaya pemrosesan gaji, mengurangi waktu dan potensi kesalahan yang diakibatkan oleh manusia.

Namun masih perlu disempurnakan lagi karena tidak setiap dokumen mencantumkan pembuat dan pengesah dokumen tersebut. Terdapat kelemahan pada dokumen yang digunakan, yaitu rekap daftar hadir sebaiknya dibuat oleh bagian personalia. Tanda terima pembayaran gaji sebaiknya dibuat rangkap dua.

\subsection{Analisis Catatan Akuntansi yang Digunakan dalam Sistem} Informasi Akuntansi Penggajian dan Pengupahan pada PT. Populer Sarana Medika

Catatan akuntansi yang digunakan dalam sistem informasi akuntansi penggajian pada PT. Populer Sarana Medika terdiri dari Jurnal Umum dan Buku Besar.

Catatan akuntansi yang digunakan oleh PT. Populer Sarana Medika sudah baik dan sesuai dengan teori sebelumnya. Hal ini dibuktikan dengan dibuatnya jurnal dan buku besar untuk 
merekam transaksi yang berkaitan dengan pemberian gaji karyawan.

\subsection{Analisis Jaringan Prosedur yang} Membentuk Sistem Informasi Akuntansi Penggajian pada PT. Populer Sarana Medika

a. Prosedur pencatatan waktu hadir karyawan PT. Populer Sarana Medika adalah sebagai berikut :

Prosedur pencatatan waktu hadir karyawan PT. Populer Sarana Medika dimulai dengan karyawan melakukan finger print (check clock) pada saat datang dan melakukan finger print (check clock) kembali pada saat pulang. Bagian Akuntansi bertugas membuat rekap daftar hadir karyawan setiap akhir bulan dan bertanggung jawab melaporkan rekap daftar hadir karyawan kepada Direktur

b. Prosedur pembayaran gaji karyawan Pembayaran gaji pokok karyawan setiap bulan dilakukan dengan mentransfer uang gaji ke rekening masing - masing karyawan.

Jaringan prosedur yang membentuk sistem informasi akuntansi penggajian pada PT. Populer Sarana Medika sudah cukup baik dan sesuai dengan teori sebelumnya. Pembayaran tunjangan karyawan dan transfer gaji pokok ke rekening masing - masing karyawan dilakukan oleh Kasir dan rekap daftar hadir karyawan dilakukan oleh bagian personalia.

Prosedur pencatatan waktu hadir karyawan masih terdapat kelemahan yaitu pengawasan pengisian daftar hadir karyawan dan rekap daftar hadir karyawan masih dilakukan oleh bagian akuntansi. Pengisian daftar hadir karyawan sebaiknya diawasi oleh Bagian Personalia. Rekap daftar hadir karyawan sebaiknya juga dibuat oleh Fungsi pencatat waktu.

\subsection{Analisis Efektivitas Pengendalian Intern dalam Sistem Informasi} Akuntansi Penggajian pada PT. Populer Sarana Medika

\section{a. Struktur Organisasi}

Struktur organisasi penggajian pada PT. Populer Sarana Medika terdiri dari bagian akuntansi yang bertanggung jawab dalam melakukan rekap daftar hadir karyawan, membuat daftar gaji karyawan, slip gaji dan Direktur yang berwenang membayarkan gaji pokok karyawan dengan mentransfer gaji ke rekening masing - masing karyawan melalui E-banking (Electronic banking). 
Efektivitas pengendalian intern sistem informasi akuntansi penggajian pada struktur organisasi PT. Populer Sarana Medika sudah cukup baik dan sesuai dengan teori yang ada karena memiliki fungsi bagian-bagian yang belum terpisah. Hal ini ditunjukkan dengan perangkapan tugas pada bagian akuntansi yang bertindak sebagai pencatat waktu hadir sekaligus sebagai pembuat daftar gaji. Perangkapan tugas tersebut dapat mengakibatkan kecurangan dalam perhitungan gaji sehingga pemberian gaji tidak sesuai dengan kinerja karyawan. Dalam sistem pengendalian yang baik fungsi pembuat daftar gaji harus terpisah dari fungsi pencatat waktu, begitu juga dengan fungsi keuangan dan juru bayar yang harus terpisah agar tidak mengakibatkan kecurangan.

\section{b. Sistem Otorisasi dan Pencatatan}

Sistem otorisasi dan pencatatan pada PT. Populer Sarana Medika yaitu besarnya gaji pokok yang diterima karyawan oleh pihak manajemen. Rekap daftar hadir karyawan yang dibuat oleh Bagian Akuntansi setiap akhir bulan dilaporkan kepada Direktur.

Efektivitas pengendalian intern pada sistem otorisasi dan pencatatan pada PT.
Populer Sarana Medika sudah baik dan sesuai teori sebelumnya. Dengan adanya dokumen - dokumen dalam sistem informasi akuntansi penggajian yang digunakan sebagai bukti penting yang berkaitan dengan prosedur penggajian karyawan.

c. Praktek yang sehat

1) Ketelitian dan kebenaran perhitungan daftar gaji dihitung kembali kebenarannya oleh Bagian Akuntansi sebelum melakukan pembayaran gaji kepada karyawan.

2) Pembayaran gaji pokok karyawan dilakukan dengan mentransfer uang gaji ke rekening masing - masing karyawan oleh Direktur.

3) Slip gaji dibuat rangkap dua. Lembar kesatu disimpan oleh Bagian Akuntansi lembar kedua untuk diberikan kepada masing masing karyawan.

Penerapan praktek yang sehat sudah baik dan sesuai dengan teori sebelumnya. Terbukti dengan dilakukannya pengecekan kembali perhitungan gaji atau pendapatan per bulan oleh Bagian Akuntansi sebelum dibayarkan ke masing - masing karyawan karena bagian akuntansi bertanggung jawab dalam pembuatan daftar gaji per bulan karyawan. Bagian 
Akuntansi juga bertanggung jawab membuat slip gaji yang dibuat dua rangkap dimana lembar kesatu disimpan oleh Bagian Akuntansi dan diberikan kepada masing-masing karyawan. Pembayaran gaji pokok karyawan dilakukan dengan mentransfer uang gaji ke rekening masing-masing karyawan oleh Direktur melalui E-banking (Electronic banking).

\section{PENUTUP}

\subsection{Simpulan}

1. Fungsi-fungsi yang terkait dalam sistem informasi akuntansi penggajian pada PT. Populer Sarana Medika kurang baik dan belum sesuai dengan teori karena pada bagian akuntansi masih merangkap sebagai pencatat waktu hadir, pembuat daftar gaji dan juga melaksanakan pembayaran gaji karyawan.

2. Dokumen-dokumen untuk penggajian pada PT. Populer Sarana Medika sudah cukup baik dan sudah sesuai dengan teori yang ada. Perusahaan memanfaatkan teknologi informasi sehingga pemrosesan penggajian dibuat secara komputerisasi. Namun masih perlu disempurnakan lagi karena tidak setiap dokumen mencantumkan pembuat dan pengesah dokumen tersebut.

3. Catatan akuntansi yang digunakan oleh PT. Populer Sarana Medika sudah baik dan sesuai dengan teori sebelumnya. Hal ini dibuktikan dengan dibuatnya jurnal dan buku besar untuk merekam transaksi yang berkaitan dengan pemberian gaji karyawan.

4. Jaringan prosedur yang membentuk sistem informasi akuntansi penggajian pada PT. Populer Sarana Medika sudah cukup baik dan sesuai dengan teori sebelumnya. Tetapi prosedur pencatatan waktu hadir karyawan masih terdapat kelemahan yaitu pengawasan pengisian daftar hadir karyawan dan rekap daftar hadir karyawan masih dilakukan oleh bagian akuntansi.

5. Sistem Informasi Akuntansi Penggajian yang telah diterapkan oleh PT. Populer Sarana Medika sudah baik dan sesuai dengan teori yang ada karena telah dilengkapi Sistem Pengendalian Intern yang memadai karena memenuhi unsurunsur Pengendalian Intern 


\subsection{Saran}

1. Dalam sistem informasi akuntansi penggajian, sebaiknya perlu adanya pemisahan tugas dan wewenang yang jelas sehingga perangkapan fungsi dapat diminimalkan serta dapat meningkatkan pengendalian intern perusahaan. Dokumen yang digunakan dalam sistem akuntansi penggajian dan pengupahan karyawan hendaknya mendapat otorisasi dari bagian yang bertanggungjawab agar dapat mencegah adanya penyelewengan.

2. Untuk memudahkan manajemen melakukan pengawasan terhadap jalannya operasional perusahaan maka diperlukan bagian khusus yang menangani masalah pengendalian intern perusahaan, karena dalam bagian ini terdapat bagian khusus yang mengawasi bagian keuangan, personalia, serta operasional perusahaan.

\section{DAFTAR PUSTAKA}

Bodnar, George H., William S. Hopwood. 2003. Sistem Informasi Akuntansi. Edisi Keenam. Terjemahan Amir Abadi Jusuf, Rudi M. Tambunan. Jakarta: Salemba Empat.
Danke Yuanita. 2012. Analisis Perancangan Sistem Informasi Akuntansi pada Siklus Penggajian dalam rangka Efektifitas Pengendalian Internal, Jurnal Berkala Ilmiah Mahasiswa Akuntansi Vol. 1. Hal.20-26.

Elder, Randal J., Mark S.B., dan Alvin A.A.. 2009. Auditing and Assurance Services An Integrated Approach, dialihbahasakan oleh Amir Abadi Jusuf. Singapore: Prentice Hall

Hidayat, Rahayu, Husaini. 2013. Analisis Penerapan Sistem Akuntansi Penggajian dan Pengupahan dalam Mendukung Pengendalian Intern. Jurnal Administrasi Bisnis Vol. 6. Hal.1-8

Mardalis. 2010. Metode Penelitian. Edisi Pertama. Jakarta: Bumi Aksara.

Mulyadi. 2001. Sistem Informasi Akuntansi. Edisi 5. Yogyakarta: Aditya Media.

Saraswaati, Darminto, Endang. 2014. Analisis Sistem Akuntansi Penggajian dan Pengupahan sebagai upaya Mendukung Tujuan 
Pengendalian Intern Perusahaan.

Jurnal Administrasi Bisnis Vol. 15.

Hal.1-9 